\title{
PENINGKATAN KINERJA GURU MELALUI SUPERVISI EDUKATIF KOLABORATIF SECARA PERIODIK DI SMP NEGERI 6 KETAPANG
}

\author{
Aklan \\ Sekolah Menengah Pertama Negeri 6 Ketapang \\ Email: Aklansmpn6@gmail.com
}

\begin{abstract}
Abstrak
Dalam melaksanakan proses pembelajaran di kelas seorang guru dituntut untuk benarbenar tepat dalam memilih model pembelajaran, memilih media yang sesuai dengan materi yang akan diajarkan, mampu mengelola kelas dengan baik, menguasai materi dengan baik, bisa memilih teknik-teknik evaluasi, mampu berkomunikasi dengan baik dengan peserta didik, serta memahami jiwa peserta didik.Untuk melaksanakan itu semua bukanlah perkara mudah, perlu latihan, butuh keseriusan, memerlukan dedikasi yang tinggi, mau mengintrospeksi diri serta terbuka untuk menerima masukan dari teman sejawat, kepala sekolah, pakar pendidikan serta instansi terkait. Agar menjadi pembiasaan dalam rangkaian kegiatan pembelajaran maka perbaikan terus menerus merupakan hal yang wajib dilakukan. Peran menjadi menyenangkan, lebih bermakna dan berhasil dalam mencapai tujuan pembeepala sekolah sebagai Kepala Satuan Pendidikan adalah dituntut untuk bisa Membantu guru dalam menuju perbaikan. Bentuk upaya yang bisa dilakukan oleh Kepala Sekolah adalah melaksanakan supervisi secara berkala kepada semua guru Sebagai bahan evaluasi bagi guru dan bukan mencari kelemahan guru.
\end{abstract}

Kata Kunci: Kinerja Guru, Survisi Edukatif Kolaboratif, Periodik

\section{PENDAHULUAN}

Menurut Undang-Undang Guru pasal 1 ayat 1 (2006:3) guru adalah pendidik profesional dengan tugas utama: mendidik, mengajar, membimbing, mengarahkan, melatih, menilai, dan mengevaluasi peserta didik pada pendidikan anak usia dini jalur pendidikan formal, pendidikan dasar dan pendidikan menengah.

Dalam rangka meningkatkan mutu pendidikan di Indonesia, pemerintah telah menetapkan Undang-Undang Sistem Pendidikan. Undang-Undang tersebut memuat dua puluh dua bab, tujuh puluh tujuh pasal dan penjelasannya. Undang-undang Sistem Pendidikan (2003:37) menjelaskan bahwa setiap pembaruhan sistem pendidikan nasional untuk memperbarui visi, misi dan strategi pembangunan pendidikan nasional. Visi pendidikan nasional di antaranya adalah (1) mengupayakan perluasan dan pemerataan kesempatan memperoleh pendidikan yang bermutu bagi seluruh rakyat Indonesia, (2) membantu dan memfasilitasi pengembangan potensi anak bangsa secara utuh sejak usia dini sampai akhir hayat dalam rangka mewujudkan masyarakat belajar, meningkatkan kesiapan masukan dan kualitas proses pendidikan untuk mengoptimalkan pembentukan kepribadian yang bermoral, (4) meningkatkan keprofesionalan dan akuntabilitas lembaga pendidikan sebagai pusat pembudayaan ilmu pengetahuan, keterampilan, pengalaman, sikap, dan nilai berdasarkan standar nasional dan global, (5) Memperdayakan peran sertamasyarakat dalam penyelenggaraan pendidikan berdasarkan prinsip otonomi dalam konteks Negara Kesatuan RI.

Menurut Syamsuddin (2005:66) ada tiga komponen utama yang saling berkaitan dan memiliki kedudukan strategis dalam kegiatan belajar mengajar. Ketiga komponen tersebut adalah kurikulum, guru, dan pembelajar (siswa). Ketiga komponen itu, guru menduduki posisi sentral sebab peranannya 
sangat menentukan. Dalam pembelajaran seorang guru harus mampu menerjemahkan nilai-nilai yang terdapat dalam kurikulum secara optimal. Walaupun sistem pembelajaran sekarang sudah tidak theacher center lagi, namun seorang guru tetap memegang peranan yang penting dalam membimbing siswa. Bahkan berdasarkan seorang guru harus mempunyai pengetahuan yang memadai baik di bidang akademik maupun pedagogik.

Menurut Djazuli (1886:2) seorang guru dituntut memiliki wawasan yang berhubungan dengan mata pelajaran yang diajarkannya dan wawasan yang berhubungan kependidikan untuk menyampaikan isi pengajaran kepada siswa. Kedua wawasan tersebut merupakan satu kesatuan yang tidak dapat dipisahkan. Seorang guru harus selalu meningkatkan kemampuan profesionalnya, pengetahuan, sikap dan keterampilannya secara terusmenerus sesuai perkembangan ilmu pengetahuan dan teknologi termasuk paradigma baru pendidikan.

Menurut Dirjen Pendidikan Dasar dan Menengah Departeman Pendidikan Nasional (2004:2) seorang guru harus memenuhi tiga standar kompetensi, di antaranya: (1) Kompetensi Pengelolaan Pembelajaran dan Wawasan Kependidikan, (2) Kompetensi Akademik/Vokasional sesuai materi pembelajaran, (3) Pengembangan Profesi. Ketiga kompetensi tersebut bertujuan agar guru bermutu, menjadikan pembelajaran bermutu juga, yang akhirnya meningkatkan mutu pendidikan Indonesia.Untuk mencapai tiga kompetensi tersebut, sekolah harus melaksanakan pembinaan terhadap guru baik melalui workshop, MGMP, diskusi dan supervisi edukatif. Hal itu harus dilakukan secara periodik agar kinerja dan wawasan guru bertambah sebab berdasarkan diskusi yang dilakukan guru di SMP Negeri 6 Ketapang, rendahnya kinerja dan wawasan guru diakibatkan (1) rendahnya kesadaran guru untuk belajar, (2) kurangnya kesempatan guru mengikuti pelatihan, baik secara regional maupun nasional, (3) kurang efektifnya MGMP, (4) supervisi pendidikan yang bertujuan memperbaiki proses pembelajaran cenderung menitikberatkan pada aspek administrasi. Untuk memperbaiki kinerja dan wawasan guru dalam pembelajaran di SMP Negeri 6 Ketapang, sekolah melaksanakan penelitian tindakan yang berkaitan dengan permasalahan di atas. Karena keterbatasan peneliti, maka penelitian ini hanya divokuskan pada supervisi edukatif saja sehingga judul penelitian tindakan tersebut adalah "Peningkatan Kinerja Guru dalam Pembelajaran di Kelas Melalui Supervisi Edukatif Kolaboratif secara Periodik". Kompetensi merupakan spesifikasi dari kemampuan, keterampilan dan sikap yang dimiliki seseorang serta penerapannya di dalam pekerjaan, sesuai dengan standar kinerja yang dibutuhkan oleh lapangan (Dirjen Dikdasmen, 2004:4).

Berdasarkan pendapat tersebut seorang yang bekerja sebagai guru, yang pekerjaan itu menurut Undang-Undang Guru tahun 2006 merupakan pekerjaan profesional maka guru harus memenuhi standar-standar minimal yang dibutuhkan oleh Depdiknas. Guru yang setiap hari selalu berhadapan dengan anak tentu menghadapi berbagai problema, baik yang berkaitan dengan anak tersebut maupun dengan lingkungan pendidikan, yang notabene mempunyai berbagai karakter, berbagai kemampuan dan motivasi, yang semuanya perlu strategi-strategi khusus yang harus dipersiapkan oleh guru maka guru tersebut harus mempersiapkan diri baik yang berkaitan dengan materi yang akan dikuasai siswa, sikap siswa, strategi yang dapat memudahkan siswa dalam memahami materi tersebut.

Dirjen Dikdasmen (2004:8) merumuskan indikator kompetensi, yang masing-masing komponen tersebut, di antaranya adalah: (a) Komponen Kompetensi Pengelolaan Pembelajaran, (b) Komponen Kompetensi Wawasan Pendidikan, (c) Komponen Kompetensi Akademik/ Vokasional, (d) Komponen Kompetensi Pengembangan Profesi.

Berkenaan dengan standar kinerja guru Sahertian dalam Kusmianto (1997: 49) bahwa, standar kinerja guru itu berhubungan dengan kualitas guru dalam menjalankan tugasnya 
seperti: (1) bekerja dengan siswa secara individual, (2) persiapan dan perencanaan pembelajaran, (3) pendayagunaan media pembelajaran, (4) melibatkan siswa dalam berbagai pengalaman belajar, dan (5) kepemimpinan yang aktif dari guru. Kinerja guru mempunyai spesifikasi tertentu. Kinerja guru dapat dilihat dan diukur berdasarkan spesifikasi/kriteria kompetensi yang harus dimiliki oleh setiap guru. Berkaitan dengan kinerja guru, wujud perilaku yang dimaksud adalah kegiatan guru dalam proses pembelajaran yaitu bagaimana kemampuan seorang guru dalam merencanakan pembelajaran, melaksanakan kegiatan pembelajaran, dan menilai hasil belajar. Supervisi merupakan salah satu tugas kepala sekolah yang bertujuan untuk membantu memperbaiki dan meningkatkan pengelolaan dari aspek yang disupervisi dan orang yang melakukan supervisi. Aspek yang disupervisi bisa berupa administrasi, dan edukatif, sedangkan orang yang melakukan supervisi adalah pengawas, kepala sekolah, instruktur mata pelajaran. Adapun orang yang disupervisi bisa kepala sekolah, guru mata pelajaran, guru pembimbing, tenaga edukatif yang lain, tenaga administrasi, dan siswa. Supervisi edukatif merupakan supervisi yang diarahkan pada kurikulum pembelajaran, proses belajar mengajar, pelaksanaan bimbingan dan konseling. Supervisi ini dapat dilakukan oleh pengawas, kepala sekolah, maupun guru senior yang sudah pernah menjadi instruktur mata pelajaran.

Menurut Dirjen Dikmenum (1884:15) pelaksanaan supervisi tersebut dapat dilakukan dengan cara (1) wawancara, (2) observasi. Jika supervisi dilakukan pengawas kepada kepala sekolah maka pengawas bisa melaksanakan wawancara dengan kepala sekolah yang berkaitan dengan kelengkapan dokumen kurikulum termasuk GBPP, buku paket dan buku penunjang. Dapat juga diarahkan pada pemahaman kepala sekolah terhadap GBPP, persiapan mengajar, kegiatan belajar mengajar, berbagai metode penyajian, penilaian, dan bimbingan \& konseling. Selain itu pengawas bisa bertanya tentang pemanfaatan sarpras, pembagian tugas guru dalam PBM, penilaian kepala sekolah terhadap guru dalam rangka pelaksanaan tugas, pengaturan penilaian siswa, dan pelaksanaan BK. Selain wawancara, kepala sekolah dapat melaksanakan observasi kepada guru dalam proses belajar mengajar atau dalam kegiatan bimbingan dan konseling. Dalam melaksanakan observasi, kepala sekolah dapat memilih satu atau beberapa kelas, serta mengamati kegiatan guru dan layanan bimbingan.

Menurut Dirjen Dikmenum (1884:16) observasi tersebut bisa berupa: (1) Observasi kegiatan belajar mengajar meliputi: (a) persiapan mengajar, (b) pelaksanaan satuan pelajaran di dalam kelas, dan (c) pelaksanaan penilaian. (2) Observasi kegiatan Bimbingan dan konseling meliputi: (a) program kegiatan bimbingan dan konseling di sekolah, (b) pelaksanaan bimbingan dan konseling di sekolah, (c) kelengkapan administrasi/ perlengkapan Bimbingan dan Konseling, (d) penilaian dan laporan. Selain di atas, supervisor harus melakukan observasi dan wawancara sekaligus yang berkaitan dengan kegiatan belajar mengajar di kelas.

Menurut Dirjen Dikmenum (1884:17) yang termasuk PBM adalah: (1) persiapan mengajar, yang terdiri atas; (a) membuat program tahunan, (b) membuat program semester, (c) membuat rencana pelaksanaan pembelajaran atau rencana pembelajaran. (2) melaksanakan PBM, yang terdiri atas: (a) pendahuluan, (b) pengembangan, (c) penerapan, (d) penutup. (3) penilaian, yang di dalamnya: (a) memiliki kumpulan soal, (b) analisis hasil belajar. Tujuan dari penelitian ini adalah (a) Ingin mendeskripsikan langkahlangkah supervisi edukatif kolaboratif secara periodik dalam melaksanakan pembelajaran, (b) Ingin mendeskripsikan langkah-langkah supervisi edukatif kolaboratif secara periodik dalam menilai prestasi belajar, (c) Ingin mendeskripsikan langkah-langkah supervisi edukatif kolaboratif secara periodik dalam melaksanakan tindak lanjut penilaian prestasi belajar siswa. (d) Ingin mendeskripsikan langkah-langkah supervisi edukatif kolaboratif secara periodik dalam menyusun rencana pembelajaran. 


\section{METODE PENELITIAN}

Penelitian ini dilaksanakan di SMP Negeri 6 Ketapang Kecamatan Delta Pawan Kabupaten Ketapang pada tahun pelajaran 2018/2019. Waktu penelitian adalah pada tahun pelajaran 2018/2019. Selama penelitian tersebut peneliti mengumpulkan data awal, menyusun program supervisi, pelaksanaan supervisi, analisis, dan tindak lanjut.

Penelitian ini merupakan penelitian tindakan maka pelaksanakan ini dilaksanakan secara siklus. Pelaksanaannya selama dua siklus. Siklus-siklus itu merupakan rangkaian yang saling berkelanjutan, maksudnya siklus kedua merupakan kelanjutan dari siklus pertama. Setiap siklusnya selalu ada persiapan tindakan, pelaksanaan tindakan, pemantauan dan evaluasi, dan refleksi.

Gambaran Pelaksanaan Siklus I (a) Persiapan Tindakan: Siklus pertama dilaksanakan selama 2 bulan yaitu pertengahan bulan Juli sampai pertengahan bulan September 2018 tahun pelajaran 2018 / 2019 dengan kegiatan sebagai berikut: Pengumpulan data awal diambil dari daftar keadaan guru untuk mengetahui pendidikan terakhir, pelatihan yang pernah diikuti guru, serta lamanya guru bertugas. Data awal kerja guru dan efektivitas pembelajaran dilihat dari hasil supervisi kunjungan kelas masingmasing guru sebelum dilaksanakan penelitian; Mengadakan pertemuan guru-guru sebagai mitra penelitian membahas langkah-langkah pemecahan masalah pembelajaran dari aspek guru, dan Peneliti; Merumuskan langkahlangkah tindakan yang akan dilaksanakan pada siklus pertama. (b) Pelaksanaan Tindakan: Mengadakan penelitian guru selama membuat program pembelajaran melalui workshop sekolah; Melaksanakan supervisi edukatif selama pembelajaran secara periodik dengan sistem kolaboratif. (c) Pemantauan dan Evaluasi: Profesional, guru yang memiliki komitmen tinggi dan kemampuan berpikir tinggi; Analitis, guru yang memiliki kemampuan berpikir tinggi, tetapi komitmennya rendah; Tidak terfokus atau bingung, guru yang memiliki komitmen tinggi, tetapi kemampuan berpikirnya rendah;
Gagal, guru memiliki komitmen rendah dan kemampuan berpikurnya juga rendah; Tindakan Peneliti sebelum pelaksanaan supervisi; Tindakan Peneliti selama pelaksanaan supervisi; Tindakan Peneliti setelah pelaksanaan supervisi; Aktivitas guru dalam melaksanakan pembelajaran di kelas. (d) Refleksi : Peneliti (Kepala Sekolah) dan Guru pada tahap ini mendiskusikan pelaksanaan proses tindakan yang dilakukan berdasarkan hasil pengamatan selama guru menyusun rencana pembelajaran, melaksanakan pembelajaran, menilai prestasi belajar, melaksanakan tindak lanjut hasil penilaian prestasi belajar siswa dan Peneliti melakukan tindakan. Hal yang didiskusikan meliputi: kesesuaian pembelajaran dengan perencanaan, materi yang digunakan pembelajaran, evaluasi pembelajaran, kesesuaian tindakan guru dengan format supervisi, dan tindak lanjut Peneliti dan guru.

Gambaran Siklus II dilaksanakan selama 2 bulan, yakni pertengahan bulan September sampai pertengahan bulan November 2018 tahun pelajaran 2018 / 2019 dan merupakan kelanjutan serta perbaikan siklus I. Kegiatan siklus kedua didasarkan pada hasil siklus pertama dengan rangkaian: (a) Persiapan Tindakan, (b) Pelaksanaan Tindakan, (c) Pemantauan dan Evaluasi, (d) Refleksi.

Teknik pengumpulan Data pada penelitian ini terdiri atas empat kegiatan pokok yakni pengumpulan data awal, data hasil analisis setiap akhir siklus, serta tanggapan lain dari guru terhadap pelaksanaan supervisi edukatif model kolaboratif.

Teknik Analisis Data dengan menggunakan analisis kualitatif dan kuantitatif. Analisis kualitatif digunakan untuk menjelaskan perubahan perilaku guru dalam pembelajaran dan perilaku Peneliti dalam melaksanakan supervisi guru. Indikator keberhasilan yang dicapai oleh peneliti dalam penelitian ini ialah apabila persentasi rata-rata keberhasilan dari keseluruhan guru meningkat. Sedangkan tolak ukur nilai keberhasilan dari seorang guru sebesar $\geq 75$. Aspek - aspek kinerja guru yang ditujukan sebagai indikator keberhasilan, diantaranya: kinerja guru dalam menyusun rencana 
pembelajaran, kinerja guru dalam melaksanakan pembelajaran, kinerja guru dalam menilai prestasi belajar siswa, kinerja guru dalam melaksanakan tindak lanjut hasil penilaian prestasi belajar siswa. Dengan meningkatnya kinerja guru maka dapat

\section{HASIL DAN PEMBAHASAN}

Siklus I :Hasil siklus I dapat dilihat pada tabel berikut ini berakibat terjadinya pembelajaran efektif yang mampu memotivasi belajar siswa dengan meningkatnya hasil belajar terutama nilai ujian semester.

Tabel 1. Hasil Penentuan Perencanaan Siklus I

\begin{tabular}{llccc}
\hline No. & \multicolumn{1}{c}{ Indikator } & $\begin{array}{c}\text { Jumlah } \\
\text { Guru }\end{array}$ & $\begin{array}{c}\text { JML Guru } \\
\text { Berhasil(Skor } \\
\geq 75\end{array}$ & $\begin{array}{c}\% \\
\text { Keber- } \\
\text { hasilan }\end{array}$ \\
\hline 1 & Mendeskripsikan Tujuan Pembelajaran & 6 & 5 & 83 \\
\hline 2 & Menentukan materi sesuai dengan kompetensi & 6 & 5 & 83 \\
\hline 3 & $\begin{array}{l}\text { Mengorganisasikan materi berdasarkan urutan } \\
\text { atau kelompok }\end{array}$ & 6 & 4 & 66,4 \\
\hline 4 & Mengalokasikan waktu & 6 & 6 & 100 \\
\hline 5 & Menentukan metode pembelajaran & 6 & 3 & 49,8 \\
\hline 6 & Merancang prosedur pembelajaran & 6 & 4 & 66,4 \\
\hline 7 & Menentukan media pembelajaran & 6 & 4 & 66,4 \\
\hline 8 & $\begin{array}{l}\text { Menentukan sumber belajar yang sesuai } \\
\text { (berupa buku, modul, program komputer dan }\end{array}$ & 6 & 5 & 83 \\
& sejenisnya) & & & \\
\hline 9 & Menentukan teknik penilaian yang sesuai & 6 & 3 & 49,8 \\
\hline & Rata - Rata Keberhasilan & & & $71,98 \%$
\end{tabular}

Tabel 2. Hasil Melaksanakan Pembelajaran Tindakan Siklus I

\begin{tabular}{llccc}
\hline No & \multicolumn{1}{c}{ Indikator } & $\begin{array}{c}\text { Jum- } \\
\text { lah } \\
\text { Guru }\end{array}$ & $\begin{array}{c}\text { JML Guru } \\
\text { Berhasil (Skor } \\
\geq 75\end{array}$ & $\begin{array}{c}\text { \% Keber- } \\
\text { hasilan }\end{array}$ \\
\hline 1 & Membuka pelajaran dengan metode yang tepat & 6 & 5 & 83 \\
\hline 2 & Menyajikan materi pelajaran secara sistematis & 6 & 4 & 66,4 \\
\hline 3 & $\begin{array}{l}\text { Menerapkan metode dan prosedur pembelajaran } \\
\text { yang telah ditentukan }\end{array}$ & 6 & 4 & 66,4 \\
\hline 4 & Mengatur kegiatan siswa di kelas & 6 & 5 & 83 \\
\hline 5 & Menentukan media pembelajaran & 6 & 4 & 66,4 \\
\hline 6 & Menggunakan sumber belajar & 6 & 4 & 66,4 \\
\hline 7 & $\begin{array}{l}\text { Memotivasi siswa dengan berbagai cara yang } \\
\text { positif }\end{array}$ & 6 & 5 & 83 \\
\hline 8 & $\begin{array}{l}\text { Melakukan interaksi dengan siswa menggunakan } \\
\text { bahasa yang komunikatif }\end{array}$ & 6 & 5 & 83 \\
\hline 9 & Memberikan pertanyaan dan umpan balik & 6 & 4 & 66,4 \\
\hline 10 & Menyimpulkan pembelajaran & 6 & 4 & 66,4 \\
\hline 11 & Menggunakan waktu secara efektif & 6 & 4 & 66,4 \\
\hline & Rata - Rata Keberhasilan & & & $72,44 \%$ \\
\hline
\end{tabular}


Tabel 3. Hasil Menilai Prestasi Belajar Siklus I

\begin{tabular}{llccc}
\hline No. & \multicolumn{1}{c}{ Indikator } & $\begin{array}{c}\text { Jumlah } \\
\text { Guru }\end{array}$ & $\begin{array}{c}\text { JML Guru } \\
\text { Berhasil(Skor } \geq \\
75\end{array}$ & $\begin{array}{c}\% \text { Keber- } \\
\text { hasilan }\end{array}$ \\
\hline 1 & Menyusun soal/perangkat penilaian & 6 & 5 & 83 \\
\hline 2 & Melaksanakan penilaian & 6 & 5 & 83 \\
\hline 3 & Memeriksa jawaban/memberi skor & 6 & 4 & 66,4 \\
\hline 4 & Menilai hasil belajar & 6 & 6 & 100 \\
\hline 5 & Mengolah hasil belajar & 6 & 4 & 66,4 \\
\hline 6 & Menganalisis hasil belajar & 6 & 4 & 66,4 \\
\hline 7 & Menyimpulkan hasil belajar & 6 & 4 & 66,4 \\
\hline 8 & Menyusun laporan hasil belajar & 6 & 6 & 100 \\
\hline 9 & Memperbaiki soal/perangkat penilaian & 6 & 6 & 100 \\
\hline & Rata - Rata Keberhasilan & & & $81,3 \%$ \\
\hline
\end{tabular}

Tabel 4. Hasil Melaksnakan Tindak Lanjut Hasil Penilaian Siklus I

\begin{tabular}{clccc}
\hline No. & \multicolumn{1}{c}{ Indikator } & $\begin{array}{c}\text { Jumlah } \\
\text { Guru }\end{array}$ & $\begin{array}{c}\text { JML Guru } \\
\text { Berhasil (Skor } \\
\geq 75\end{array}$ & $\begin{array}{c}\% \\
\text { Keber- } \\
\text { hasilan }\end{array}$ \\
\hline 1 & $\begin{array}{l}\text { Mengidentifikasi kebutuhan tindak lanjut } \\
\text { hasil penilaian }\end{array}$ & 6 & 4 & 66,4 \\
\hline 2 & Menyusun program tindak lanjut & 6 & 5 & 83 \\
\hline 3 & Melaksanakan tindak lanjut & 6 & 3 & 49,8 \\
\hline 4 & $\begin{array}{l}\text { Mengevaluasi hasil tindak lanjut hasil } \\
\text { penilaian }\end{array}$ & 6 & 3 & 49,8 \\
\hline 5 & $\begin{array}{l}\text { Menganalisis hasil evaluasi program } \\
\text { tindak lanjut hasil penilaian }\end{array}$ & 6 & 3 & 49,8 \\
\hline & Rata-rata Keberhasilan & & & $59,76 \%$ \\
\hline
\end{tabular}

Siklus II

Tabel 5. Hasil Penentuan Perencanaan Siklus II

\begin{tabular}{llccc}
\hline No. & \multicolumn{1}{c}{ Indikator } & $\begin{array}{c}\text { Jumlah } \\
\text { Guru }\end{array}$ & $\begin{array}{c}\text { JML Guru } \\
\text { Berhasil (Skor } \\
\geq 75\end{array}$ & $\begin{array}{c}\% \\
\text { Keber- } \\
\text { hasilan }\end{array}$ \\
\hline 1 & Mendeskripsikan Tujuan Pembelajaran & 6 & 6 & 100 \\
\hline 2 & Menentukan materi sesuai dengan kompetensi & 6 & 6 & 100 \\
\hline 3 & $\begin{array}{l}\text { Mengorganisasikan materi berdasarkan urutan } \\
\text { atau kelompok }\end{array}$ & 6 & 5 & 83 \\
\hline 4 & Mengalokasikan waktu & 6 & 6 & 100 \\
\hline 5 & Menentukan metode pembelajaran & 6 & 5 & 83 \\
\hline 6 & Merancang prosedur pembelajaran & 6 & 5 & 83 \\
\hline 7 & Menentukan media pembelajaran & 6 & 5 & 83 \\
\hline 8 & $\begin{array}{l}\text { Menentukan sumber belajar yang sesuai } \\
\text { (berupa buku, modul, program komputer dan } \\
\text { sejenisnya) }\end{array}$ & 6 & 6 & 100 \\
\hline 9 & Menentukan teknik penilaian yang sesuai & 6 & 6 & 100 \\
\hline$\quad$ Rata - Rata Keberhasilan & & & $92,44 \%$ \\
\hline
\end{tabular}


Tabel 6. Hasil Melaksanakan Pembelajaran Tindakan Siklus II

\begin{tabular}{llccc}
\hline No. & \multicolumn{1}{c}{ Indikator } & $\begin{array}{c}\text { Jumlah } \\
\text { Guru }\end{array}$ & $\begin{array}{c}\text { JML Guru } \\
\text { Berhasil (Skor } \geq \\
75)\end{array}$ & $\begin{array}{c}\% \\
\text { Keber- } \\
\text { hasilan }\end{array}$ \\
\hline 1 & $\begin{array}{l}\text { Membuka pelajaran dengan metode yang } \\
\text { tepat }\end{array}$ & 6 & 6 & 100 \\
\hline 2 & Menyajikan materi pelajaran secara sistematis & 6 & 5 & 83 \\
\hline 3 & $\begin{array}{l}\text { Menerapkan metode dan prosedur } \\
\text { pembelajaran yang telah ditentukan }\end{array}$ & 6 & 5 & 83 \\
\hline 4 & Mengatur kegiatan siswa di kelas & 6 & 6 & 100 \\
\hline 5 & Menentukan media pembelajaran & 6 & 5 & 83 \\
\hline 6 & Menggunakan sumber belajar & 6 & 6 & 100 \\
\hline 7 & $\begin{array}{l}\text { Memotivasi siswa dengan berbagai cara yang } \\
\text { positif }\end{array}$ & 6 & 6 & 100 \\
\hline 8 & $\begin{array}{l}\text { Melakukan interaksi dengan siswa } \\
\text { menggunakan bahasa yang komunikatif }\end{array}$ & 6 & 6 & 100 \\
\hline 9 & Memberikan pertanyaan dan umpan balik & 6 & 5 & 83 \\
\hline 10 & Menyimpulkan pembelajaran & 6 & 6 & 100 \\
\hline 11 & Menggunakan waktu secara efektif & 6 & 6 & 100 \\
\hline & Rata - Rata Keberhasilan & & $93,81 \%$ \\
\hline
\end{tabular}

Tabel 7. Hasil Menilai Prestasi Belajar Siklus II

\begin{tabular}{clccc}
\hline No. & \multicolumn{1}{c}{ Indikator } & $\begin{array}{c}\text { Jumlah } \\
\text { Guru }\end{array}$ & $\begin{array}{c}\text { JML Guru } \\
\text { Berhasil (Skor } \geq \\
75)\end{array}$ & $\begin{array}{c}\% \\
\text { Keber- } \\
\text { hasilan }\end{array}$ \\
\hline 1 & Menyusun soal/perangkat penilaian & 6 & 5 & 83 \\
\hline 2 & Melaksanakan penilaian & 6 & 5 & 83 \\
\hline 3 & Memeriksa jawaban/memberi skor & 6 & 5 & 83 \\
\hline 4 & Menilai hasil belajar & 6 & 6 & 100 \\
\hline 5 & Mengolah hasil belajar & 6 & 6 & 100 \\
\hline 6 & Menganalisis hasil belajar & 6 & 5 & 83 \\
\hline 7 & Menyimpulkan hasil belajar & 6 & 5 & 83 \\
\hline 8 & Menyusun laporan hasil belajar & 6 & 6 & 100 \\
\hline 9 & Memperbaiki soal/perangkat penilaian & 6 & 100 \\
\hline & Rata - Rata Keberhasilan & & & $90.56 \%$ \\
\hline
\end{tabular}


Tabel 8. Hasil Melaksanakan Tindak Lanjut Hasil Penilaian Siklus II

\begin{tabular}{clccc}
\hline No. & \multicolumn{1}{c}{ Indikator } & $\begin{array}{c}\text { Jumlah } \\
\text { Guru }\end{array}$ & $\begin{array}{c}\text { JML Guru } \\
\text { Berhasil (Skor } \\
\geq 75)\end{array}$ & $\begin{array}{c}\% \\
\text { Keber- } \\
\text { hasilan }\end{array}$ \\
\hline 1 & $\begin{array}{l}\text { Mengidentifikasi kebutuhan tindak lanjut } \\
\text { hasil penilaian }\end{array}$ & 6 & 5 & 83 \\
\hline 2 & Menyusun program tindak lanjut & 6 & 5 & 83 \\
\hline 3 & Melaksanakan tindak lanjut & 6 & 5 & 83 \\
\hline 4 & $\begin{array}{l}\text { Mengevaluasi hasil tindak lanjut hasil } \\
\text { penilaian }\end{array}$ & 6 & 5 & 83 \\
\hline 5 & $\begin{array}{l}\text { Menganalisis hasil evaluasi program } \\
\text { tindak lanjut hasil penilaian }\end{array}$ & 6 & 5 & 83 \\
\hline & Rata-rata Keberhasilan & & & $83 \%$ \\
\hline
\end{tabular}

Temuan pertama, kinerja guru meningkat dalam membuat perencanaan pembelajaran. Hal ini terjadi karena adanya kerja sama antara guru kelas yang satu dengan lainnya serta diberi pengarahan oleh peneliti. Langkahlangkah yang dapat meningkatkan kinerja guru dalam membuat persiapan pembelajaran adalah: (1) Peneliti memberikan format supervisi dan jadwal supervisi pada awal tahun pelajaran atau awal semester. Pelaksanaan supervisi tidak hanya dilakukan sekali, (2) Peneliti selalu menanyakan perkembangan pembuatan perangkat pembelajaran (mengingatkan betapa pentingnya perangkat pembelajaran), (3) satu minggu sebelum pelaksanaan supervisi perangkat pembelajaran, Peneliti menanyakan format penilaian, jika format yang diberikan pada awal tahun pelajaran tersebut hilang, maka guru yang bersangkutan disuruh memfotokopi arsip sekolah. Jika di sekolah masih banyak format seperti itu maka guru tersebut diberi kembali. Bersamaan dengan memberi/menanyakan format, Peneliti meminta pengumpulan perangkat pembelajaran yang sudah dibuatnya untuk untuk diteliti kelebihan dan kekurangannya, (4) Peneliti memberikan catatan-catatan khusus pada lembaran untuk diberikan kepada guru yang akan disupervisi tersebut. (5) Peneliti dalam menilai perangkat pembelajaran penuh perhatian dan tidak mencerminkan sebagai penilai. Peneliti bertindak sebagai kolaborasi. Peneliti membimbing, mengarahkan guru yang belum bisa, tetapi Peneliti juga menerima argumen guru yang positif. Dengan adanya itu, terciptalah hubungan yang akrap antara guru dan Peneliti. Tentu saja ini akan membawa nilai positif dalam pelaksanaan pembelajaran.

Temuan kedua, kinerja guru meningkat dalam melaksanakan pembelajaran. Dalam penelitian tindakan ini ternyata dari 6 guru hampir semuanya mampu melaksanakan pembelajaran dengan baik. Hal ini terbukti dari hasil supervisi. Langkah-langkah yang dilakukan untuk meningkatkan pelaksanaan pembelajaran berdasarkan penelitian tindakan ini adalah: (1) Peneliti yang mengamati guru mengajar tidak sebagai penilai tetapi sebagai rekan bekerja yang siap membantu guru tersebut, (2) Selama pelaksaaan supervisi di di kelas guru tidak menganggap Peneliti sebagai penilai karena sebelum pelaksanaan supervisi guru dan Peneliti telah berdiskusi permasalahan-permasalahan yang ada dalam pembelajaran tersebut, (3) Peneliti mencatat semua peristiwa yang terjadi di dalam pembelajaran baik yang positif maupun yang negatif, (4) Peneliti selalu memberi contoh pembelajaran yang berorientasi pada Modern Learning. (5) Jika ada guru yang pembelajarannya kurang jelas tujuan, penyajian, umpan balik, Peneliti memberikan contoh 
bagaimana menjelaskan tujuan, menyajikan, memberi umpan balik kepada guru tersebut, (6) Setelah guru diberi contoh pembelajaran modern, Peneliti setiap dua atau tiga minggu mengunjungi atau mengikuti guru tersebut dalam proses pembelajaran.

Temuan ketiga, kinerja guru meningkat dalam menilai prestasi belajar siswa. Pada penelitian tindakan yang dilakukan di SMP Negeri 6 Ketapang Kecamatan Delta Pawan Kabupaten Ketapang ini ternyata pelaksanaan supervisi edukatif kolaboratif secara periodik memberikan dampak positif terhadap guru dalam menyusun soal/perangkat penilaian, melaksanakan, memeriksa, menilai, mengolah, menganalisis, menyimpulkan, menyusun laporan dan memperbaiki soal. Sebelum diadakan supervisi edukatif secara kolaboratif, guru banyak yang mengalami kesulitan dalam melaksankan penilaian. Langkah-langkah yang dilakukan dalam supervisi edukatif kolaboratif secara periodik yang dapat meningkatkan kinerja guru adalah: (1) Peneliti berdiskusi dengan guru dalam pembuatan perangkat penilaian sebelum dilaksanakan supervisi, (2) Guru melaksanakan penilaian sesuai dengan aturan yang telah ditetapkan bersama Peneliti yang sebagai kolaboratif dalam pembelajaran, (3) Guru membuat kriteria penilaian yang berkaitan dengan penskoran, pembobotan, dan pengolahan nilai, yang sebelum pelaksanaan supervisi didiskusikan dengan peneliti, (4) Guru menganalisis hasil penilaian dan melaorkannya kepada urusan kurikulum.

Temuan keempat, Kinerja guru meningkat dalam melaksanakan tindak lanjut hasil penilaian prestasi belajar peserta didik. Langkah-langkah yang dapat meningkatkan kinerja guru dalam supervisi edukatif kolaboratif adalah: (1) Peneliti dan guru bersama-sama membuat program tindak lanjut hasil penilaian, (2) Peneliti memberi contoh pelaksanaan tindak lanjut, yang akhirnya dilanjutkan oleh guru dalam pelaksanaan yang sebenarnya, (3) Peneliti mengajak diskusi pada guru yang telah membuat, melaksanakan, dan menganalis program tindak lanjut.

Temuan kelima, Kinerja guru meningkat dalam menyusun program pembelajaran, melaksanakan pembelajaran, menilai prestasi belajar, dan melaksanakan tindak lanjut hasil prestasi belajar siswa.

\section{SIMPULAN DAN SARAN Simpulan}

Berdasarkan temuan hasil penelitian bahwa : Pelaksanaan supervisi edukatif kolaboratif secara periodik dapat meningkatkan kinerja guru. Ada empat hal yang dikemukakan dalam penelitian tindakan ini, yakni : (1) Peningkatan kinerja guru dalam menyusun rencana pembelajaran, (2) Peningkatan kinerja guru dalam melaksanakan pembelajaran, (3) Peningkatan kinerja guru dalam menilai prestasi belajar, (4) Peningkatan kinerja guru dalam melaksanakan tindak lanjut hasil penilaian prestasi belajar siswa.

\section{Saran}

Berdasarkan temuan-temuan penelitian tindakan ini, ada beberapa saran yang perlu disampaikan kepada pengambil kebijakan sekolah, di antaranya adalah (1) Supervisi terhadap semua guru perlu dilakukan secara periodik dan ditetapkan pada awal tahun pelajaran (pada saat pembagian tugas), (2) Supervisi edukatif ternyata membawa peningkatan kinerja guru dan hasil belajar siswa jika dilaksanakan secara kolaboratif, (3) Supervisi edukatif kolaboratif akan bermakna jika Penelitinya adalah teman sejawat yang sudah mampu pada mata pelajaran yang bersangkutan, (4) Perlu memberi kesempatan pada guru-guru yang dianggap sudah mampu mensupervisi guru lain. 
DAFTAR PUSTAKA

Depdiknas. 2006. Undang-undang Sistem Pendidikan Nasional : Jakarta Departemen Pendidikan Nasional.

Direktorat Pendidikan Menegah Umum (Dikmenum). Universitas. PTS

Djazuli. 2000. Evaluasi Hasil Belajar : Yokyakarta : Pustaka Belajar.
Suharsimi, Suhardjono dan Supardi. 2006. Penelitian Tindakan Kelas. Jakarta : PT Bumi Aksara

Suhardjono. 2009. Tanya jawab tentang PTK dan PTS, naskah buku.

Syamsudin. 2005. Psikologi Pendidikan. Bandung: PT. Remaja Rosda Karya AM. Sudirman 